https://doi.org/10.15407/frg2018.06.508

УДК 581.132:632.954:633.15

\title{
EFFECTIVENESS OF AUXIN-LIKE HERBICIDE HALAUXIFEN- METHYL MIXTURES WITH OTHER HERBICIDES FOR CANADA THISTLE (CIRSIUM ARVENSE) CONTROL IN WHEAT CROPS
}

\author{
Ye.Yu. MORDERER ${ }^{1}$, A.M. SYCHUK ${ }^{1}$, O.P. RODZEVYCH ${ }^{1}$, V.V. PAVLENKO ${ }^{2}$, \\ O.M. SARBASH ${ }^{2}$ \\ ${ }^{1}$ Institute of Plant Physiology and Genetics, National Academy of Sciences of \\ Ukraine \\ 31/17 Vasylkivska St., 03022, Kyiv, Ukraine \\ e-mail: morderer@ifrg.kiev.ua \\ ${ }^{2}$ Ukraine DowDuPont Agriculture Division \\ 30 A Spaska St., Business Center «Podil Plaza», 04070, Kyiv, Ukraine
}

The effectiveness of perennial dicotyledonous weed Canada thistle (Cirsium arvense) controlling by the mixtures of new auxin-like herbicide halauxifen-methyl with acetolactate synthase (ALS) inhibitors florasulam and pyroxsulam was investigated in field trials in wheat crops. The effect of mixtures of halauxifen-methyl with ALS inhibitors with the addition of ALS inhibitor tribenuron-methyl and synthetic auxin clopyralid was also studied. It has been shown that adding tribenuron-methyl and clopyralid to the mixtures of halauxifen-methyl with pyroxsulam and florasulam increases the effectiveness of Canada thistle control in wheat. For effective Canada thistle control, treatment of wheat plantings by the mixtures of halauxifen-methyl with pyroxsulam and florasulam with adding tribenuronmethyl or clopyralid should be carried out during the period from the phase of tillering to the phase of second internode formation in the crop, when the thistle plants reach the phase of the rosette or the beginning of stem elongation.

Key words: Cirsium arvense (L.) Scop., Triticum aestivum L., Canada thistle, wheat, weed control, herbicide, herbicides mixtures, halauxifen-methyl.

Rapid cost increase in the development of new active ingredients led to the delay of the update rate of the herbicides range [5]. At the same time, this limited range complicates the implementation of measures aimed to prevent the occurrence of herbicide-resistant weed biotypes, which is based on the integrated application of herbicides with different action mode to protect individual crops and rotation of herbicides during crop rotation $[8,9]$. In this regard, the development of a new herbicide halauxifen-methyl, manufactured by Dow AgroSciences, is a significant achievement.

Halauxifen-methyl belongs to the synthetic auxins, but it embodies a new group of chemicals - arylpicolinates that possess this mode of action. According to the effectiveness, halauxifen-methyl is exceeding all known auxin-like herbicides and is approaching the most effective modern herbicides from the class of acetolactate synthase (ALS) inhibitors [1]. 
Field trials conducted across different regions of the world, including Ukraine, showed that halauxifen-methyl applied in cereals at the rates of a few grams of active ingredient per hectare effectively controls annual dicotyledonous weeds such as catchweed (Galium aparine), as well as weeds of the families of Brassicaceae, Amaranthaceae, Papaveraceae, and so on. At the same time, in these low rates, the effect of halauxifen-methyl on the annual dicotyledonous weed from the family of Aster is insufficient. Therefore, previous work has shown rationality to use halauxifen-methyl in the mixtures with ALS-inhibiting herbicide florasulam for their effective control [2]. For simultaneous control of annual dicotyledonous and cereal weed in the wheat crops, the use of a mixture of halauxifen-methyl with another ALS-inhibiting herbicide pyroxsulam was effective [3].

Complex tank mixes utilizing ALS inhibitors and synthetic auxins are widely used to protect wheat and maize crops, because the mixtures of these active ingredients allow to expand the spectrum of controlled weed species and reduce the likelihood of resistance to ALS herbicide. However, addition of synthetic auxins, such as dicamba or 2,4-D to ALS inhibitors, significantly increases the total herbicide loading, which leads to an increase of pesticide pressure on agrophytocenoses. The use of halauxifenmethyl, which is used at rates equivalent to that of ALS-inhibiting herbicides, can solve this problem. Additionally, the use of dicamba, which has a rather significant persistence, worsens the ecological properties of complex preparations, because residues of dicamba in the soil can adversely affect the crop rotation. The half-life of halauxifen-methyl does not exceed 15 days in the soil under normal conditions of humidity and temperature; therefore, complex preparations based on halauxifen-methyl do not pose a threat to subsequent crop rotations [1].

As noted above, for controlling a wide range of weeds in wheat, it is commercially expedient to compose halauxifen-methyl with ALS-inhibiting herbicides, florasulam and pyroxsulam. At the same time, taking into account the inadequate effectiveness of these active ingredients on perennial dicotyledonous weed of Aster family Canada thistle (Cirsium arvense (L.) Scop.), on condition of the high level of weediness of wheat plantings by this perennial weed, it may be necessary to increase the action of mixtures of halauxifen-methyl with florasulam and pyroxsulam with herbicides, which are effective against thistle.

One of the factors that determine the effectiveness of synthetic auxins and ALS inhibitors tank mixtures is the synergistic interaction of these herbicides, which leads to the increase of the phytotoxic action of these mixtures [4]. However, this kind of interaction is clearly observed only for annual weeds control. When applying mixtures to control perennial weed, the effects of interaction are more complex. In particular, it has been found that ALS inhibitors may prevent the translocation of synthetic auxin clopyralid to the root system of Canada thistle [7]. As a result, the thistle plants treated by the mixtures of ALS inhibitors and synthetic auxins may rapidly regrow, and the effectiveness of their control is less than that with the separate application of synthetic auxins. In addition, it is known that the effectiveness of the complex herbicides significantly depends on the phase in which the thistle plants are present at the time of treatment [6]. 
Individual ALS-inhibiting herbicides, in particular tribenuron-methyl, and synthetic auxins, in particular clopyralid, have high effectiveness of action on the thistle plants. Because of the complex nature of the interaction of synthetic auxins with ALS-inhibiting herbicides for the effects on perennial weeds, it is necessary to determine which class of herbicides and under what conditions it is appropriate to use for improving perennial dicotyledonous weed Canada thistle control in wheat crops by the mixtures of halauxifen-methyl with florasulam and pyroxsulam.

\section{Materials and Methods}

Determination of the herbicides mixtures efficacy was carried out during 2014 to 2015 on the fields of experimental farming of the Institute of Plant Physiology and Genetics of the National Academy of Sciences of Ukraine, in Glevakha Village of Vasylkiv District of Kyiv Region $\left(50^{\circ} 16^{\prime} \mathrm{N}, 30^{\circ} 18^{\prime} \mathrm{E}\right)$. The experimental station is located on the boundary of the Polesye and Forest-steppe zones. The climate is moderate, with rainfall within 520 to $645 \mathrm{~mm}$. Soil is sandy clay loam with organic matter of $1.6 \%$, and $\mathrm{pH}$ of 5.6.

The experiments were carried out using spring wheat Zimojarka (2014) and winter wheat Smugljanka (2015) plantings with Canada thistle invasion. The experiments were arranged using a randomized complete block design with four replicates. Each experiment included weedy control, plots were $2.5 \mathrm{~m}$ wide and $5 \mathrm{~m}$ in length.

The treatment by herbicides was carried out in two terms: (A) when a significant proportion of thistles was still in the early phases of development; (B) 10 to 15 days after treatment in the term A, when most thistle plants reached the phases of rosette and stem elongation. The weather conditions before, at the time, and after application of herbicides are given in Table 1. Herbicide treatment was carried out using a backpack sprayer with compressed air $(4 \mathrm{kPa})$, the bar width of $2.5 \mathrm{~m}$, a number of nozzles of 5 , a distance to the target object of $50 \mathrm{~cm}$, the speed of movement $5 \mathrm{~km} / \mathrm{h}$, the flow rate of the working solution 300 1/ha.

Experimental herbicide formulations GF-3122, WG (pyroxsulam, $250 \mathrm{~g} / \mathrm{kg}+$ halauxifen-methyl, $66.67 \mathrm{~g} / \mathrm{kg}+$ antidote cloquintocet, $354 \mathrm{~g} / \mathrm{kg}$ ) $(0.075 \mathrm{~kg} / \mathrm{ha})$, and GF-3313, WG (florasulam, $100 \mathrm{~g} / \mathrm{kg}+$ halauxifenmethyl, $100 \mathrm{~g} / \mathrm{kg}+$ antidote cloquintocet, $70.8 \mathrm{~g} / \mathrm{kg})(0.05 \mathrm{~kg} / \mathrm{ha})$ by Dow

TABLE 1. The weather conditions before, during, and after applications of herbicides

\begin{tabular}{|c|c|c|c|c|c|c|c|c|c|c|c|}
\hline \multirow{3}{*}{ Date } & & \multirow{3}{*}{$\begin{array}{c}\text { Air } \\
\text { tempe- } \\
\text { rature at } \\
\text { applica- } \\
\text { tion }\left({ }^{\circ} \mathrm{C}\right)\end{array}$} & \multirow{3}{*}{$\begin{array}{l}\text { Wind } \\
\text { speed at } \\
\text { appli- } \\
\text { cation } \\
(\mathrm{m} / \mathrm{s})\end{array}$} & \multicolumn{6}{|c|}{ Precipitation $(\mathrm{mm})$} & \multirow{3}{*}{$\begin{array}{c}\text { Time } \\
\text { to 1st } \\
\text { precipi- } \\
\text { tation } \\
\text { after } \\
\text { applica- } \\
\text { tion (h) }\end{array}$} & \multirow{3}{*}{$\begin{array}{c}\text { 1st } \\
\text { precipi- } \\
\text { tation } \\
\text { after } \\
\text { applica- } \\
\text { tion } \\
(\mathrm{mm}) \\
\end{array}$} \\
\hline & & & & \multicolumn{2}{|c|}{$\begin{array}{c}\text { Weeks } \\
\text { before } \\
\text { application }\end{array}$} & \multicolumn{4}{|c|}{$\begin{array}{l}\text { Weeks after } \\
\text { application }\end{array}$} & & \\
\hline & & & & 2 & 1 & 1 & 2 & 3 & 4 & & \\
\hline 14.05 .2014 & A & 21 & 2 & 8 & 13 & 88 & 11 & 31 & 9 & 22 & 5 \\
\hline 26.05.2014 & B & 25 & 1 & 77 & 22 & 31 & 9 & 2 & 9 & 25 & 0.5 \\
\hline 25.04.2015 & A & 18 & 1 & 0.9 & 0.6 & 0.2 & 28 & 10 & 28 & 8 & 10 \\
\hline 05.05 .2015 & $\mathrm{~B}$ & 18 & 1 & 0.2 & 22 & 12 & 32 & 0.2 & 0.1 & 4 & 0.2 \\
\hline
\end{tabular}


AgroSciences were used as halauxifen-methyl mixtures with ALS inhibiting herbicides. ALS inhibitor Granstar, WG (tribenuron-methyl, $750 \mathrm{~g} / \mathrm{kg}$ ) (25 g/ha) by Dupont and auxin-like herbicide Lontrel Grand, WG (clopyralid, $750 \mathrm{~g} / \mathrm{kg})(120 \mathrm{~g} / \mathrm{ha})$ by Dow AgroSciences were used alone and in the tank mixtures with GF-3313 and GF-3122. All treatments with GF3313 and GF-3122 included adjuvant Surfer (1 l/ha).

The assessments of weed were carried out before applications of herbicides, 30 days after the first treatment, and before harvesting. The effectiveness of herbicide action in 30 days after the first treatment was evaluated visually with a decrease in the amount and degree of inhibition of the thistle plants and expressed as a percentage: $0 \%$, no phytotoxic effect; $100 \%$, complete destruction of weed. Before harvesting, the effectiveness of herbicides was determined by the weight method and calculated using the following formula:

$$
E_{i}(\%)=100\left(M_{\kappa}-M_{i}\right) / M_{\kappa},
$$

where $E_{i}(\%)$ is the effectiveness of thistles controlling; $M_{i}$, raw matter fresh weight of the aboveground part of thistle plants on the experimental plot; $M_{\kappa}$, raw matter fresh weight of the aboveground part of the thistle plants on the control plot. Aboveground part of thistle plants on each plot was cut off and immediately weighed on an electronic scales.

Statistical processing of the results was performed using the computer program APM 8, used to determine the significant difference by Tukey's HSD test.

\section{Results and Discussion}

In 2014, treatment of spring wheat planting in term A was carried out when the crop was in the phase of tillering (BBCH 26). At this moment, Canada thistle invasion amounted to $0.4-0.6 \mathrm{pcs} / \mathrm{m}^{2}$. Approximately a third of the plants were in the phase of 4 to 5 leaves (BBCH 14-15), a third - in the phase of the rosette (BBCH 30), and a third - in the phase of stem elongation $(\mathrm{BBCH} 32)$. In term $\mathrm{B}$, treatment was performed after 12 days, when spring wheat reached the phase of second internode formation (BBCH 32). At this moment, Canada thistle invasion increased to 1.0$1.5 \mathrm{pcs} / \mathrm{m}^{2}$. Distribution of plants by phases of development has changed in comparison with term $\mathrm{A}$ : in the phase of 3-5 leaves (BBCH 13-15) there were up to $5 \%$ of plants, in the phase of the rosette $(\mathrm{BBCH} 30)-$ $40 \%$, in the phase of stem elongation (BBCH $32-34)-55 \%$ of the thistle plants. In addition to Canada thistle, spring wheat planting had invasion of annual dicotyledonous weed common sowthistle (Sonchus oleraceus L.) $\left(0.2 \mathrm{pcs} / \mathrm{m}^{2}\right)$ and scentiess mayweed (Matricaria inodora L.) $\left(0.5 \mathrm{pcs} / \mathrm{m}^{2}\right)$.

In 2015, in term A, the treatment of the winter wheat plantings was carried out when the crop was in the phase of tillering (BBCH 25). At this time, Canada thistle invasion was $3.0 \mathrm{pcs} / \mathrm{m}^{2}$. Up to half of the thistle plants had 4-5 leaves (BBCH 14-15), and the other half was in the phase of the rosette $(\mathrm{BBCH} 30)$. In term $\mathrm{B}$, treatment was conducted after 10 days, when winter wheat reached the phase of second internode formation (BBCH 32). Thistle invasion has increased at this moment, although slight$\mathrm{ly}$, to $3.5 \mathrm{pcs} / \mathrm{m}^{2}$. In the phase of $3-5$ leaves $(\mathrm{BBCH} \mathrm{13-15)}$ there were 
up to $5 \%$ of plants, in the phase of the rosette $(\mathrm{BBCH} 30)-20 \%$, in the phase of stem elongation (BBCH $32-34)-70 \%$ of thistle plants. The weed species composition in the winter wheat planting was significantly more diverse than in that the spring wheat planting. In addition to Canada thistle, in winter wheat plantings, several species of annual dicotyledonous weeds were presented: field pansy (Viola arvensis Murr.) $-10 \mathrm{pcs} / \mathrm{m}^{2}$; forking larkspur (Consolida regalis $\mathrm{S}$. F. Gray) $-3 \mathrm{pcs} / \mathrm{m}^{2}$; scentiess mayweed $-0.5 \mathrm{pcs} / \mathrm{m}^{2}$; catchweed (Galium aparine L.) $-0.3 \mathrm{pcs} / \mathrm{m}^{2}$; flixweed tensy mustard (Descurainia Sophia (L.) Webb.) $-0.3 \mathrm{pcs} / \mathrm{m}^{2}$; as well as annual Gramineae weed, loose silky-bent (Apera spica-venti (L.) Pal. Beauv) $-5 \mathrm{pcs} / \mathrm{m}^{2}$.

The assessments of weeds carried out after herbicides application showed high effectiveness of annual weeds control by the mixtures of halauxifen-methyl with florasulam and pyroxsulam. In 2014, annual thistle and scentiess mayweed were controlled for $100 \%$ in all variants regardless of the time of application. In 2015, scentiess mayweed was also controlled for $100 \%$ in all variants, forking larkspur and flixweed tensy mustard was controlled for $100 \%$ in all variants, except those where clopyralid was used separately, catchweed was not controlled only in variants with a separate application of clopyralide and tribenuron-methyl. Field pansy and loose silky-bent were controlled for $100 \%$ by the mixture of halauxifen-methyl and pyroxsulam, regardless of the time of application and addition of tribenuron-methyl or clopyralid.

The results of determining the effectiveness of Canada thistle control by herbicides are given in Table 2 . Statistical analysis showed that the variation of data is quite significant, which is due to the heterogeneity of invasion of distinct plots by thistle plants, which at the time of treatment were in different phases of development. However, it is possible to divide the variants clearly into three groups: with a minimum, average, and maximum effectiveness of thistles control. In the 2014 experiment, the average group is divided into two, averages 1 and 2 (Table 3). Differences were valid only between extreme groups, and there were no differences between variants that are found in adjacent groups. It is evident from these data that during both years of research, the minimum effectiveness of thistle control was observed in variants 1 and 4, in which the mixtures of halauxifen-methyl with florasulam and pyroxsulam were used in term A. In 2015, in the last assessment, the same group got the variant 6 , in which the plantings were treated in term A by the mixture of halauxifen-methyl and florasulam with the addition of tribenuron-methyl. Positioning variants in the group with maximum effectiveness was not so unambiguous. Differences in the distribution of variants were observed between the first assessment and second assessment, and the years of research. At the same time, it is clearly seen that the maximum effectiveness of thistles control was observed only in the variants where herbicides were introduced in term B.

This results can be explained by the fact that, first, during spraying in the term A, not all thistle plants have sprouted and come under influence of herbicides, and second, less effectiveness can be explained by the fact that during the treatment of planting in the term A, a significant part of the thistle plants is still in the early stages of development when they have 
TABLE 2. Effectiveness of Canada thistle control (\%) by herbicides 30 DAT in the term A and before wheat harvesting

\begin{tabular}{|c|c|c|c|c|c|c|c|}
\hline \multirow[t]{3}{*}{ No. } & \multirow[t]{3}{*}{ Treatment } & \multirow{3}{*}{$\begin{array}{l}\text { Rate kg/ha, } \\
\text { l/ha }\end{array}$} & \multirow[t]{3}{*}{ Term } & \multicolumn{4}{|c|}{$\%$ of control } \\
\hline & & & & \multicolumn{2}{|c|}{2014} & \multicolumn{2}{|c|}{2015} \\
\hline & & & & $30 \mathrm{DAT}^{1}$ & harvesting $^{2}$ & $30 \mathrm{DAT}^{1}$ & harvesting $^{2}$ \\
\hline 1 & GF-3122 + Surfer & $0.075+1.0$ & A & $63.3^{\mathrm{cd}}$ & $40.0^{\mathrm{d}}$ & $68.8^{\mathrm{c}}$ & $65.0^{\mathrm{c}}$ \\
\hline 2 & $\begin{array}{l}\text { GF-3122 + Surfer }+ \\
\quad+\text { Lontrel Grand }\end{array}$ & $0.075+1,0+0.12$ & A & $81.8^{\mathrm{abc}}$ & $80.0^{\mathrm{abc}}$ & $81.8^{\mathrm{abc}}$ & $73.8^{\mathrm{abc}}$ \\
\hline 3 & $\begin{array}{c}\text { GF-3122 }+ \text { Surfer }+ \\
+ \text { Granstar }\end{array}$ & $0.075+1,0+0.12$ & A & $76.8^{\mathrm{abc}}$ & $53.3^{\text {bcd }}$ & $78.0^{\mathrm{abc}}$ & $86.3^{\mathrm{abc}}$ \\
\hline 4 & GF-3313 + Surfer & $0.05+1.0$ & A & $52.5^{\mathrm{d}}$ & $50.0^{\text {cd }}$ & $74.7^{\mathrm{bc}}$ & $70.0^{\mathrm{bc}}$ \\
\hline 5 & $\begin{array}{l}\text { GF-3313 + Surfer }+ \\
\quad+\text { Lontrel Grand }\end{array}$ & $0.05+1.0+0.12$ & A & $76.3^{\mathrm{abc}}$ & $67.5^{\mathrm{a}-\mathrm{d}}$ & $82.0^{\mathrm{abc}}$ & $81.3^{\mathrm{abc}}$ \\
\hline 6 & $\begin{array}{c}\text { GF-3313 }+ \text { Surfer }+ \\
+ \text { Granstar }\end{array}$ & $0.05+1.0+0.025$ & A & $77.5^{\mathrm{abc}}$ & $75.0^{\mathrm{abc}}$ & $80.6^{\mathrm{abc}}$ & $70.0^{\mathrm{bc}}$ \\
\hline 7 & Lontrel Grand & 0.12 & A & $81.3^{\mathrm{abc}}$ & $78.8^{\mathrm{abc}}$ & $82.0^{\mathrm{abc}}$ & $88.0^{\mathrm{abc}}$ \\
\hline 8 & Granstar & 0.025 & A & $83.8^{\mathrm{abc}}$ & $66.3^{\mathrm{a}-\mathrm{d}}$ & $84.8^{\mathrm{abc}}$ & $82.5^{\mathrm{abc}}$ \\
\hline 9 & GF-3122 + Surfer & $0.075+1.0$ & B & $65.0^{\mathrm{bcd}}$ & $68.8^{\mathrm{a}-\mathrm{d}}$ & $82.9^{\mathrm{abc}}$ & $78.8^{\mathrm{abc}}$ \\
\hline 10 & $\begin{array}{l}\text { GF-3122 + Surfer + } \\
\quad+\text { Lontrel Grand }\end{array}$ & $0.075+1.0+0.12$ & B & $86.3^{\mathrm{ab}}$ & $88.8^{\mathrm{a}}$ & $92.7^{\mathrm{a}}$ & $87.5^{\mathrm{abc}}$ \\
\hline 11 & $\begin{array}{c}\text { GF-3122 }+ \text { Surfer }+ \\
+ \text { Granstar }\end{array}$ & $0.075+1.0+0.12$ & B & $87.5^{\mathrm{a}}$ & $86.3^{\mathrm{a}}$ & $90.0^{\mathrm{ab}}$ & $91.0^{\mathrm{ab}}$ \\
\hline 12 & GF-3313 + Surfer & $0.05+1.0$ & B & $68.8^{\mathrm{a}-\mathrm{d}}$ & $67.5^{\mathrm{a}-\mathrm{d}}$ & $83.8^{\mathrm{abc}}$ & $87.5^{\mathrm{abc}}$ \\
\hline 13 & $\begin{array}{l}\text { GF-3313 + Surfer }+ \\
\quad+\text { Lontrel Grand }\end{array}$ & $0.05+1.0+0.12$ & B & $86.3^{\mathrm{ab}}$ & $80.0^{\mathrm{abc}}$ & $90.7^{\mathrm{ab}}$ & $96.3^{\mathrm{a}}$ \\
\hline 14 & $\begin{array}{c}\text { GF-3313 }+ \text { Surfer }+ \\
+ \text { Granstar }\end{array}$ & $0.05+1.0+0.025$ & B & $83.8^{\mathrm{abc}}$ & $85.0^{\mathrm{a}}$ & $93.9^{\mathrm{a}}$ & $94.8^{\mathrm{ab}}$ \\
\hline 15 & Lontrel Grand & 0.12 & B & $87.5^{\mathrm{a}}$ & $78.8^{\mathrm{abc}}$ & $93.9^{\mathrm{a}}$ & $90.0^{\mathrm{abc}}$ \\
\hline 16 & Granstar & 0.025 & B & $80.0^{\mathrm{abc}}$ & $81.3^{\mathrm{ab}}$ & $92.7^{\mathrm{a}}$ & $91.3^{\mathrm{ab}}$ \\
\hline \multicolumn{2}{|c|}{ Tukey's HSD $\mathrm{P}=05$} & & & 21.85 & 30.24 & $\begin{array}{l}16.13- \\
19.37\end{array}$ & 25.65 \\
\hline
\end{tabular}

Note. DAT - days after treatment; 1 - percent of control 30 DAT in the term A based on visual estimates $(0=$ no visual symptoms, $100=$ complete plant death $) ; 2-$ percent of control before wheat harvesting based by the weight method and calculated using the formula 1 .

TABLE 3. Distribution of variants of the trials on the effectiveness of Canada thistle control

\begin{tabular}{l|c|c|c|c}
\hline \multirow{2}{*}{$\begin{array}{c}\text { Effective- } \\
\text { ness }\end{array}$} & \multicolumn{4}{|c}{ Variant number } \\
\cline { 2 - 5 } & 2014 & 2015 & 2014 & 2015 \\
\cline { 2 - 5 } & \multicolumn{2}{|c}{ Assessment 1 } & 1,4 & $1,4,6$ \\
Minimal & 1,4 & 1,4 & $3,5,8,9,12$ & $2,3,5,7,8,9$, \\
Medium 1 & 9,12 & $2,3,5,6,7,8,9,12$ & $2,6,7,13,15$ & $10,12,15$ \\
Medium 2 & $2,3,5,6,7,8,14,16$ & & $10,11,14,16$ & $11,13,14,16$ \\
Maximum & $10,11,13,15$ & $10,11,13,14,15,16$ & & \\
\hline
\end{tabular}


not yet reached the phase of the rosette. As it is known, the action of auxin-like herbicides mixtures with ALS-inhibiting herbicides is greater if the thistle plants are in the phase of rosette or stem elongation. Differences in the positioning of variants between assessments 1 and 2 can be explained by the fact that the phytotoxic activity of clopyralid develops more rapidly than the action of tribenuron-methyl, especially in the action on the thistle plants that reached significant proportions at the time of treatment. Therefore, in the first assessment, variants 10, 13, and 15, where clopyralid was used in mixtures or individually, were in the group with maximum effectiveness for both years, and variants 14 and 16, where the mixture or separately used tribenuron-methyl, only in 2015. On the contrary, when conducting a second assessment, the speed of phytotoxic action is irrelevant, and effectiveness is mainly determined by the ability of herbicides to block the regrowth of perennial thistle plants; during both years, the maximum effectiveness was observed in variants 11, 14, and 16, in which tribenuron-methyl was applied alone or added to the mixtures of halauxifenmethyl with florasulam and pyroxsulam. At the same time, variant 10, in which clopyralid was added to the mixture of halauxifen-methyl and pyroxsulam, was in the group with maximum efficacy only in 2014, and variant 13 , in which clopyralid was added to the mixture of halauxifen-methyl with florasulam only in 2015.

However, with these data, it cannot be concluded that adding ALSinhibiting herbicide tribenuron-methyl to the mixture of halauxifen-methyl with florasulam and pyroxsulam is more effective than adding synthetic auxin clopyralid. Because for both years, variant 15 , in which clopyralid was used separately, has gone into the middle group, and variant 16, in which tribenuron-methyl was used separately - in the group with maximum effectiveness. Consequently, with the chosen rates, the own action of tribenuron-methyl slightly exceeded the effect of clopyralid, resulting in the addition of tribenuron-methyl to the mixtures of halauxifen-methyl with pyroxsulam and florasulam which was more effective than the addition of clopyralid.

Thus, the obtained results draw the following conclusions: adding tribenuron-methyl and clopyralid to the mixtures of halauxifen-methyl with pyroxsulam and florasulam increases the effectiveness of perennial dicotyledonous Canada thistle control in wheat crops.

For effective Canada thistle control, treatment of wheat plantings by the mixtures of halauxifen-methyl with pyroxsulam and florasulam with adding tribenuron-methyl or clopyralid should be carried out from the period of phase tillering to the phase of second internode formation in the crop, when the thistle plants have reached the phase of the rosette or beginning of stem elongation.

\section{REFERENCES}

1. Anonymous (2013). ArylexTM Active - Technical Bulletin. http://www.arylex.com/en.

2. Anonymous (2016). Quelex ${ }^{\circledR}$ herbicide. http://www.dowagro.com/en-us/usag/productsolution-finder/herbicides/quelex.

3. Anonymous (2017). Rexade ${ }^{\mathrm{TM}}$ GoDRI ${ }^{\mathrm{TM}}$ herbicide with Arylex Active. http://www.dowagro.com/ennz/newzealand/productfinder/herbicides/rexade. 
4. Issaks, M.A., Hatzios, K.K., Wilson, H.P. \& Toler, J. (2006). Halosulfuron and 2,4-D mixtures' effects on common lambsquarters (Chenopodium album). Weed Technol., 20, pp. 137-142.

5. Kraehmer, H., van Almsick, A., Beffa, R., Dietrich, H., Eckes, P., Hacker, E., Hain, R., Strek, H.J., Stuebler, H. \& Willms, L. (2014). Herbicides as weed control agents: state of the art: II. Recent achievements. Plant Physiol., 166, pp. 1132-1148.

6. Morderer, Ye.Yu., Nizkov, Ye.I. \& Lukjanchenko, O.S. (2008). The efficacy of creeping thistle (Cirsium arvense (L.) Scop.) control on wheat and barley by the mixtures of AHAS-inhibiting herbicides and clopyralid. Physiol. and Biochem. of Cultivated Plants, 40, No. 4, pp. 310-317.

7. Nizkov, Ye.I., Rodzevich, O.P., Omelchuk, S.T., Borisenko, A.A., Korshun, A.M. \& Morderer, Ye.Yu. (2014). The efficacy of action and the traslocation of systemic auxinic herbicide clopyralid to the root system of Cirsium arvense upon application in the mixtures with herbicides acetolactate synthase inhibitors. Plant Physiol. and Genetics, 45, No. 4, pp. 337-342.

8. Norsworthy, J.K., Ward, S.M., Shaw, D.R., Llewellyn, R.S., Nichols, R.L., Webster, T.M., Bradley, K.W., Frisvold, G., Powles, S.T., Burgos, N.R., Witt, W.W. \& Barret, M. (2012). Reducing the risk of herbicide resistance: best management practices and recommendation. Weed Sci., Special Issue, pp. 31-62.

9. Vencil, W.K., Nichols, R.L., Webster, T.M., Soteres, J.K., Mallory-Smith, C., Burgos, N.R., Johnson, W.G. \& McCleland, M.R. (2012). Herbicides resistance: toward an understanding of resistance development and the impact of herbicide-resistant crop. Weed Sci., Special Issue, pp. 2-30.

\title{
ЕФЕКТИВНЇСТЬ ЗАСТОСУВАННЯ СУМЇШЕЙ АУКСИНОПОДІББНОГО ГЕРБІЦЦИДУ ГАЛАКСИФЕН-МЕТИЛУ 3 ІІНШИМИ ГЕРБІЦЦИДАМИ ДЛЯ КОНТРОЛЮВАННЯ В ПОСІВАХ ПШЕНИЦІ ОСОТУ РОЖЕВОГО (ПОЛЬОВОГО) (CIRSIUM ARVENSE)
}

\author{
Є.Ю. Мордерер ${ }^{1}$, А.М. Сичук $^{1}$, О.П. Родзевич ${ }^{1}$ В.В. Павленко ${ }^{2}$, О.М. Сарбаш ${ }^{2}$ \\ ${ }^{1}$ Їнститут фізіології рослин і генетики Національної академії наук України, \\ Київ \\ ${ }^{2}$ Український сільськогосподарський підрозділ компанії ДоуДюпон, Київ
}

У польових дослідах в посівах пшениці досліджували ефективність контролювання багаторічного дводольного бур'яну осоту рожевого (польового) сумішами нового ауксиноподібного гербіциду галаксифен-метилу з гербіцидами інгібіторами ацетолактатсинтази (АЛС) флорасуламом і піроксуламом. Вивчали дію сумішей галаксифен-метилу з гербіцидами інгібіторами АЛС за додавання інгібітору АЛС трибенурон-метилу та синтетичного ауксину клопіраліду. Показано, що додавання трибенурон-метилу й клопіраліду до сумішей галаксифен-метилу з флорасуламом і піроксуламом підвищує ефективність контролювання осоту рожевого (польового) в посівах пшениці. Встановлено, що для ефективного контролювання осоту рожевого (польового) обробку посівів пшениці сумішами галаксифен-метилу з флорасуламом і піроксуламом з додаванням трибенурон-метилу або клопіраліду необхідно проводити впродовж періоду від фази кущіння до фази утворення другого міжвузля у культури, коли рослини осоту рожевого (польового) досягають фази розетки або початку видовження стебла.

Ключові слова: Cirsium arvense (L.) Scop., Triticum aestivum L., осот рожевий (польовий), пшениця, контролювання бур'янів, гербіциди, суміші гербіцидів, галаксифен-метил. 
Ye.Yu. MORDERER, A.M. SYCHUK, O.P. RODZEVYCH ET AL.

\section{ЭФФЕКТИВНОСТЬ ПРИМЕНЕНИЯ СМЕСЕЙ АУКСИНОПОДОБНОГО ГЕРБИЦИДА ГАЛАКСИФЕН-МЕТИЛА С ДРУГИМИ ГЕРБИЦИДАМИ ДЛЯ КОНТРОЛИРОВАНИЯ В ПОСЕВАХ ПШЕНИЦЫ БОДЯКА ПОЛЕВОГО (CIRSIUM ARVENSE)}

\section{Е.Ю. Мордерер ${ }^{1}$ А.М. Сычук ${ }^{1}$, Е.П. Родзевич${ }^{1}$, В.В. Павленко ${ }^{2}$ О.Н. Сарбаш ${ }^{2}$}

${ }^{1}$ Институт физиологии растений и генетики Национальной академии наук Украины, Киев

2Украинское сельскохозяйственное подразделение компании ДоуДюпон, Киев

В полевых опытах в посевах пшеницы исследовали эффективность контролирования многолетнего двудольного сорняка бодяка полевого смесями нового ауксиноподобного гербицида галаксифен-метила с гербицидами ингибиторами ацетолактатсинтазы (АЛС) флорасуламом и пироксуламом. Изучали действие смесей галаксифен-метила с гербицидами ингибиторами АЛС при добавлении ингибитора АЛС трибенурон-метила и синтетического ауксина клопиралида. Показано, что добавление трибенуронметила и клопиралида к смесям галаксифен-метила с флорасуламом и пироксуламом повышает эффективность контролирования бодяка полевого в посевах пшеницы. Установлено, что для эффективного контролирования бодяка полевого обработку посевов пшеницы смесями галаксифен-метила с флорасуламом и пироксуламом с добавлением трибенурон-метила или клопиралида необходимо проводить в течение периода от фазы кущения до фазы образования второго междоузлия у культуры, когда растения бодяка полевого достигают фазы розетки или начала удлинения стебля.

Ключевые слова: Cirsium arvense (L.) Scop., Triticum aestivum L., бодяк полевой, пшеница, контролирование сорняков, гербициды, смеси гербицидов, галаксифен-метил. 